\title{
Improvements in nutrient digestibility and performance of broiler chickens fed a wheat-and- rye based diet supplemented with enzymes
}

\author{
S. Steenfeldt ${ }^{1}$ and D. Pettersson ${ }^{2}$ \\ 'Danish Institute of Agricultural Sciences, \\ Department of Animal Nutrition and Physiology, Research Centre Foulum \\ P.O. Box 50, DK-8830 Tjele, Denmark \\ 'Novo Nordisk Enzyme Business A/S, Feed Applications \\ DK-2880 Bagsvard, Denmark
}

(Rccived 5 October 2000; accepted 22 January 2001)

\begin{abstract}
The aim of the present experiment was to study the effect of an increasing level of an enzyme preparation on intestinal viscosity, ileal digestibility and performance of broiler chickens fed a diet containing wheat $(63 \%)$ and rye $(9.35 \%)$ in the period from $0-21$ days of agc. Four diets, containing $11.98 \mathrm{MJ} \mathrm{ME} / \mathrm{kg}$ fecd and $19.52 \%$ protein, were included in the experiment: Control (basal diet), L, M, and $\mathrm{H}$ (basal diet with 100,200 and $300 \mathrm{mg}$ Bio-Feed Wheat $\mathrm{CT} / \mathrm{kg}$, respectively). Feed conversion in chickens fed the diet with the medium dose of enzyme was significantly $(\mathrm{P}<0.002)$ better compared with the control group and the chickens fed the diet with the lowest dose of enzyme by 5.0 and $3.3 \%$, respectively. Weight gain of chickens fed diet $M$ was improved by $5.3 \%$, and was significantly $(\mathbf{P}<0.0008)$ different from all the other groups. Enzyme addition reduced viscosity in jejunum $(P<0.007)$ and ileum $(P<0.05)$, diet $L$ being the exception. A significant $(\mathrm{P}<0.001)$ improvement in ileal protein digestibility was found in the chickens fed diet $\mathrm{M}$, the increase being $12.4 \%$ compared with the control, confirming the results found on performance. Enzyme addition to the other groups increased the ileal protein digestibility on average by $3.5 \%$, but not significantly different from the control. A pronounced effect of enzyme supplementation was found on the ileal fat digestibility of chickens fed diet $M$, the improvement $(P<0.0007)$ being as high as $17.0 \%$. In addition, the ileal digestibility of organic matter in chickens fed diet $M$ was improved by $8.9 \%$ compared with the control group $(\mathrm{P}<0.02)$.
\end{abstract}

KEY WORDS; wheat, intestinal viscosity, nutrient digestibility, performance, chickens, enzymes 


\section{INTRODUCTION}

The carbohydrates in the wheat kernel make up $60-80 \%$ of dry matter and are thus the major component and wheat is the most important energy source in diets for poultry in many European countrics. In most feedstuffs, the starch and sugars are digested to a high extent by endogenous enzymes, whereas poultry have no enzymes present in the small intestine which can degrade the non-starch-polysaccharides (NSP) (Scott et al., 1982). The NSP in feed are a complex group of components differing widely in chemical composition, physical properties and physiological activity. NSP are present in the cell walls both as soluble and insoluble components, dependent on their location in the different botanical fractions of the wheat kernel. The main constituents of wheat endosperm cell walls are arabinoxylans (AX), whereas the $\mathrm{AX}$ and the beta-glucans predominate in wheat aleurone layer, and $\mathrm{AX}$ and cellulose in cell walls of pericarp/testa (Mares and Stone, 1973; Basic and Stone, 1981). In a study by Choct and Annison (1992) it was established that especially the soluble AX in wheat possess antinutritive activity, primarily caused by their ability to increase digesta viscosity. Enzymatic depolymerisation of soluble NSP decrease their viscous nature, as was shown for the content of AX in a rye- and wheat-based diet by Bedford and Classen (1992), and as a result the performance of broiler chickens were improved. Since intact cell wall encapsulate the nutrients making them unavailable for digestion and absorption in the small intestine, it has been indicated that disruption of cell wall material and the release of nutrients could be partly responsible for improved digestibility of enzyme-treated diets (Pettersson and Åman, 1989).

The aim of the present experiment was to study the effect of increasing level of an enzyme preparation on intestinal viscosity, ileal digestibility and performance of broiler chickens fed a diet containing wheat and rye.

\section{MATERIAL AND METHODS}

Diets and enzymes

The composition of the basal diet is given in Table 1. The wheat used was cultivar „Pepital” and harvested at the site of Research Centre Foulum in Jutland, Denmark. The cultivar of the rye was not known. The basal diet containing wheat and rye in order to simulate a viscous wheat, was formulated to contain $6 \%$ less energy than the NRC (1994) recommendations, and was supplemented with amino acids to meet the NRC recommendations for broiler chickens. Four 
TABLE 1

Composition of the basal diet

\begin{tabular}{lc}
\hline Ingredients, \% & Basal diet \\
\hline Wheat & 63.00 \\
Ryc & 9.35 \\
Soyabean meal, dehulled, toasted & 18.00 \\
Fish meal & 3.00 \\
Animal fat (tallow) & 2.45 \\
Methionine (40\%) & 0.60 \\
Lysine (40\%) & 0.60 \\
Calcium carbonate & 1.60 \\
Monocalcium phosphate & 0.80 \\
Natrium chloride & 0.20 \\
Vitamin/mineral premix' & 0.35 \\
Cholin chloride (50\%) & 0.05 \\
& \\
Calculated analysis & \\
MJ ME/kg feed & 11.98 \\
protein, \% & 19.52 \\
\hline
\end{tabular}

' the vitamin and mineral premix provided per kg of diet: vit. A, $16800 \mathrm{lU}$; vit. $\mathrm{D}_{3}, 3500 \mathrm{IU}$; vit. E, $42 \mathrm{mg}$; vit. $\mathrm{K}_{3}, 3.5 \mathrm{mg}$; vit. $\mathrm{B}_{1}, 1.4 \mathrm{mg}$; vit. $\mathrm{B}_{2}, 11.2 \mathrm{mg}$; vit. $\mathrm{B}_{6}, 4.2 \mathrm{mg}$; D-pantothenic acid, $15 \mathrm{mg}$; niacin, $56 \mathrm{mg}$; folic acid, 2. I mg; biotin, $0.14 \mathrm{mg}$; vit. $\mathrm{B}_{12}, 0.03 \mathrm{mg}$; Fe, $112 \mathrm{mg}$; Zn, $112 \mathrm{mg}$; Mn, $140 \mathrm{mg} ; \mathrm{Cu}, 2$ l mg; I, $0.8 \mathrm{mg} ; \mathrm{Se}, 0.4 \mathrm{mg}$

experimental diets were prepared: control (basal diet without enzyme), L - with $100 \mathrm{mg}, \mathrm{M}$ - with $200 \mathrm{mg}$ and $\mathrm{H}$ - with $300 \mathrm{mg}$ of Bio-Feed Wheat CT added to the basal diet. The enzymes were added to the basal diet in form of dry powder. The enzyme, supplied by Novo Nordisk $\mathrm{A} / \mathrm{S}$, is a mono-component xylanase with improved activity against arabinoxylans, originated from Thermomyces and contained $1000 \mathrm{FXU}(\mathrm{W}) / \mathrm{g}$ product as measured by internal methods based on a colour release from a dyed arabinoxylan (according to producer).

\section{Housing, chickens and experimental design}

Two hundred and fifty two day-old male broiler chickens (Ross) were randomly allotted to 3 three-tier battery cages with raised floors, each of the batteries contained 12 pens, with a $1-\mathrm{cm}$ squared wire mesh bottom. The first 7 days of age, a plastic mat with $0.1 \mathrm{~cm}$ squared mesh was placed upon the wire bottom. Each pen $\left(28 \times 48 \times 48 \mathrm{~cm}^{3}\right)$, representing one replicate, housed 9 chickens. Each pen was equipped with a feeding trough outside, and two water cups inside. The 4 experimental diets were randomly assigned to 28 pens, given a total of 7 replicates per treatment. All treatments were represented in each block and on each 
of the three tiers. Light was continuous during the whole experimental period. The batteries were electrically heated, and the temperature was gradually reduced from $33^{\circ} \mathrm{C}$ (one-day old) to $22^{\circ} \mathrm{C}$ until day 21 , where the ambient temperature was kept constant at $22^{\circ} \mathrm{C}$. The ventilation in the house (Poultry Unit F37) was automatically regulated.

The 4 diets were given to the broiler chickens during the period of 0-24 days. Diets and water were supplied ad libitum and the feed given as mash. All chickens in each pen were weighed on days $0,7,14$, and 21 . The chickens were inspected daily and dead chickens were weighed at the time of removal. Feed intake per pen (corrected for feed wastage) was recorded at the same time and feed conversion was calculated on a pen weight basis. When calculating feed conversion, the body weights of dead chickens were also included. The experiment complied with the guidelines of the Danish Ministry of Justice with respect to animal experimentation and care of animals under study.

\section{Intestinal measurements}

Viscosity. Viscosity measurements were performed at day 22 of age. Three chickens from each pen (replicate) per treatment were killed by a lethal dose of pentobarbital sodium and the small intestine was ligated to avoid post-mortem movements of digesta. The digesta was collected from the end of the duodenal loop to Meckel's diverticulum (jejunum samples) and from Meckel'diverticulum to $2 \mathrm{~cm}$ above the ileo-caecal junction (ileum samples). Jejunum and ileum samples were pooled and placed directly in one centrifuge tube $(10 \mathrm{ml})$. The centrifuge tubes with fresh digesta were maintained on ice, centrifuged at $12,000 \mathrm{xg}$ for 10 minutes, and viscosity (in centipoise, $\mathrm{cp}=1 / 100$ dyne second $\mathrm{cm}^{-2}$ ) of the supernatant was measured immediately in a Brookfield Digital DV-II cone/plate viscometer (Brookfield Engineering Laboratorics, Stoughton, MA, USA) maintained at $40^{\circ} \mathrm{C}$ and shear rates of $1.15-450 \mathrm{~s}^{-1}$. Absolute viscosity is presented at shear rate $90 \mathrm{~s}^{-1}$.

Small intestinal content. The experimental diets containing chromic oxide $(0.5 \%$ of dry matter) was given to the chickens during a 4 -day adaptation period (20-23 days of age). At 24 days of age the remaining chickens from each pen per replicate per treatment were killed by a lethal dose of pentobarbital. Immediately after death, the content of the last $25 \mathrm{~cm}$ of ileum was collected, except the last $2 \mathrm{~cm}$ before the ileo-caccal junction. All material collected from the chickens in each pen was pooled, representing one replicate, and immediately stored at $-20^{\circ} \mathrm{C}$. The samples were analysed for dry matter, ash, fat, nitrogen and chromic oxide (marker).

pH. $\mathrm{pH}$ of caeca content was measured in three of the chickens from each replicate per treatment at day 24 . The $\mathrm{pH}$ was measured by inserting a $\mathrm{pH}$ elec- 
trode (model pHC4000-8, Radiometer, Copenhagen) into the caeca with content and $\mathrm{pH}$ was noted when a steady state was obtained. The $\mathrm{pH}$ determination was repeated in both caeca and the values per replicate given as an average of the two measurements.

\section{Chemical analysis}

Diets and digesta were freeze dried before analysis and the dry matter (DM) content of the material was determined after drying at $105^{\circ} \mathrm{C}$ for $8 \mathrm{~h}$. All analyses were performed in duplicate. Protein $(6.25 \times \mathrm{N})$ was determined by the Kjeldahl method using Kjell-Foss 16200 autoanalyser and energy by a LECO AC 300 automated calorimeter system 789-500 (LECO, St.Joseph, Michigan, USA). Ash was analysed according to the AOAC (1990) and fat (hydrochloric acid-fat) was extracted with diethyl ether after acid-hydrolysis (Stoldt, 1952). $\mathrm{Cr}_{2} \mathrm{O}_{3}$ was determined using the method of Schürch et al. (1950). Starch was analysed by the method of Aman and Hesselman (1984), and sugar by the method of Jacobsen (1981). NSP were analysed according to Bach Knudsen (1997).

\section{Calculations and statistical analysis}

The content of polysaccharides was calculated as anhydrosugars, and the apparent ileal digestibility of fat, protein, organic matter and crude carbohydrates were calculated relatively to the chromic oxide marker. The content of crude carbohydrates $(\%)$ was calculated from the concentration of $\mathrm{N}$, ash and fat as: crude carbohydrates $=100-6.25 \times \mathrm{N}$ - ash - fat.

A randomised complete block design was used, the single pen representing the experimental unit (replicate). The results are presented as means and standard error of means (SEM) calculated by standard procedures. The dependent variables were tested by ANOVA according to a general linear model (GLM) procedure (SAS Institute Inc., 1990) comprising fixed effects of treatment, block and tier. Normality of data was tested by a Univariate procedure, and the means of the variables were tested for variance homogeneity by Bartlett's test. Feed intake was included in the model as a covariate when analysis of production parameters was performed. Prior to statistical analysis, data for viscosity measurements in jejunum and ileum contents were logarithmically transformed to stabilise variance between groups. The significance of difference between treatment means was separated when appropriate using the Ryan-Einot-Gabriel-Welsch multiple F-test (SAS Institute Inc., 1990). Differences were considered significant when $\mathrm{P}<0.05$. Correlation analyses were performed using GLM (SAS Institute Inc., 1990). 


\section{RESULTS}

\section{Diets}

The chemical analysis of the basal diet (Table 1) and the three main ingredients, wheat, rye, soyabean meal is shown in Table 2. The total content of NSP measured in the wheat and rye used was $10.19 \%$ of DM and $13.11 \%$ of DM, respectively, and the AX content amounted approximately to $62-63 \%$ of total NSP. The NSP-fraction of soyabean meal contained $30 \%$ galactose $(4.31 \%$ of DM), which is the main component. The content of $\mathrm{AX}$ in soyabean meal was around $22 \%$ of the NSP fraction. The content of soluble NSP in the wheat used in the present experiment was low being less than $1 \%$ of the DM content. In comparison the rye contained $3.12 \%$ of DM, approximately $24 \%$ of the total NSP fraction. The low content of soluble NSP in the wheat suggests that viscosity may not be a great problem in chickens fed diets based on this wheat. However, inclusion with $9.35 \%$

TABLE 2

Chemical analysis of the basal diet, wheat, rye and soyabean meal, $\%$ of dry matter

\begin{tabular}{lccrc}
\hline & Basal diet & Wheat & Rye & Soyabean meal \\
\hline Dry matter & 88.28 & 87.62 & 88.18 & 90.64 \\
Ash & 7.92 & 1.41 & 1.86 & 6.78 \\
Protein $(6.25 \mathrm{xN})$ & 22.14 & 12.84 & 10.58 & 55.39 \\
Fat $(\mathrm{HCL})$ & 4.47 & 2.34 & 2.03 & 2.71 \\
Starch & 42.98 & 66.80 & 62.36 & 1.49 \\
Sugar & 5.74 & 1.30 & 1.43 & 12.88 \\
& & & & \\
NSP' & & & & \\
cellulose & 1.69 & & & \\
NCP & & $\mathrm{t}$ & $\mathrm{t}$ & \\
fucose & $\mathrm{t}$ & $\mathrm{t}$ & $\mathrm{t}$ & $0.25(0.05)$ \\
rhamnose & $2.13(0.49)^{3}$ & $2.33(0.08)$ & $3.10(0.88)$ & $2.18(0.05)$ \\
arabinose & $3.07(0.54)$ & $4.16(0.25)$ & $5.03(1.19)$ & $1.03(0.22)$ \\
xylose & $0.33(0.10)$ & $0.19(0.02)$ & $0.40(0.13)$ & $0.81(0.20)$ \\
mannose & $1.09(0.34)$ & $0.25(0.06)$ & $0.46(0.18)$ & $4.31(1.00)$ \\
galactose & $0.94(0.31)$ & $1.09(\mathrm{t})$ & $2.56(0.52)$ & $0.35(\mathrm{t})$ \\
glucose & $0.71(0.30)$ & $0.39(0.11)$ & $0.42(0.22)$ & $2.41(1.08)$ \\
uronic acid & & & & \\
Total NSP & $9.95(2.08)$ & $10.19(0.52)$ & $13.11(3.12)$ & $14.40(3.57)$ \\
\hline
\end{tabular}

$\mathrm{t}$, trace

1 Non-starch polysaccharides

${ }^{2}$ Non-cellulosic polysaccharides

${ }^{3}$ values in parentheses are soluble NSP 
of rye in the diet resulted in a higher content of soluble NSP in the basal diet produced, which would have been the case with a more viscous wheat. The content of total NSP in the basal diet was analysed to be $9.95 \%$ of DM, AX amounted to $52 \%$ of total NSP and the content of soluble NSP was $2.08 \%$ of DM, accounting for $21 \%$ of the NSP fraction.

\section{Broiler performance}

The results of addition with increasing doses of enzyme to the basal diet on broiler performance (0-21 days of age) are presented in Table 3. Compared to the control, feed conversion (FC) of the enzyme supplemented diets was improved by $1.8,5.0$ and $3.4 \%$ (diet $\mathrm{L}, \mathrm{M}$ and $\mathrm{H}$, respectively), the effect being statistically significant $(\mathrm{P}<0.002)$ for diet $\mathrm{M}$ and $\mathrm{H}$. The effect of enzyme supplementation on $\mathrm{FC}$ in chickens fed diet $\mathrm{M}$ was significantly $(\mathrm{P}<0.002)$ better than in chickens fed the diet $\mathrm{L}$. The $\mathrm{FC}$ of the chickens fed diet $\mathrm{M}$ was significantly different from the control during both the 2 nd and 3 rd week of life, whereas the other groups given enzyme supplemented diets were significantly $(\mathrm{P}<0.0001)$ different from the control in week 3 only (Figure 1). Feed intake did not have a significant effect on FC.

Weight gain (WG) of the chickens fed diet $\mathrm{M}$ was improved by $5.3 \%$, significantly different $(\mathrm{P}<0.0008)$ from all the other groups in the period from $0-21$ days

TABLE 3

Performance' and digesta viscosity' of broiler chickens fed a rye/wheat based diet supplemented with different enzymes ( 3 weeks of age)

\begin{tabular}{|c|c|c|c|c|c|c|}
\hline \multirow{2}{*}{$\begin{array}{l}\text { Experimental } \\
\text { diets }^{2}\end{array}$} & \multirow{2}{*}{$\begin{array}{c}\text { Wcight gain } \\
\mathrm{g}\end{array}$} & \multirow{2}{*}{$\begin{array}{c}\text { Feed intake } \\
\qquad\end{array}$} & \multirow{2}{*}{$\begin{array}{c}\text { Feed } \\
\text { conversion } \\
\mathrm{g} / \mathrm{g}\end{array}$} & \multicolumn{2}{|c|}{ Viscosity, cps } & \multirow{2}{*}{$\begin{array}{c}\text { Mortality } \\
\%\end{array}$} \\
\hline & & & & jejunum & ileum & \\
\hline Control & $494.13^{b}$ & 798.70 & $1.617^{a}$ & $6.84^{i}$ & $12.64^{\mathrm{a}}$ & 3.2 \\
\hline$B F W-L$ & $488.50^{\mathrm{b}}$ & 774.67 & $1.588^{\mathrm{ab}}$ & $4.96^{a b}$ & $9.42^{\mathrm{ib}}$ & 3.2 \\
\hline BFW-M & $520.30^{a}$ & 798.13 & $1.536^{\mathrm{c}}$ & $3.52^{\mathrm{b}}$ & $5.92^{b}$ & 0.0 \\
\hline $\mathrm{BFW}-\mathrm{H}$ & $486.92^{\mathrm{b}}$ & 761.46 & $1.564^{\mathrm{bc}}$ & $3.53^{\mathrm{b}}$ & $5.89^{\mathrm{b}}$ & 6.3 \\
\hline SEM $^{3}$ & 5.32 & 20.55 & 0.02 & 0.93 & 2.80 & 2.44 \\
\hline \multicolumn{7}{|l|}{ P-value: } \\
\hline Diet & 0.0008 & NS & 0.002 & 0.007 & 0.05 & NS \\
\hline Feed intake & 0.0001 & & NS & & & NS \\
\hline
\end{tabular}

' values are means of 7 replicates. Means within columns with different letters are significantly different $(\mathrm{P}<0.05)$. NS (not significant) refers to $\mathrm{P}>0.05$

2 control: Basal diet without enzymes. L: Basal diet with $100 \mathrm{mg}$ enzyme $/ \mathrm{kg}$. M: Basal diet with $200 \mathrm{mg}$ enzyme $/ \mathrm{kg}$. I: Basal dict with $300 \mathrm{mg}$ enzyme $/ \mathrm{kg}$

3 standard error of mean 
of age (Table 3). The effect of diet M on WG was most pronounced in the second week of age, where the WG of chickens fed this diet were significantly $(\mathrm{P}<0.0001)$ higher than found in the other groups (Figure 1). This effect was not observed in the last week of the experimental period. Feed intake had a significant $(\mathrm{P}<0.0001)$ effect on WG during the periods from 7-14 and 14-21 days of age, respectively. The difference in feed intake between treatments was not significant during the three age periods, or from $0-21$ days of age (Table 3). Mortality (\%) was highest in the group fed diet $\mathrm{H}$, reaching a level of $6.3 \%$ at 21 days (Table 3 ). The higher mortality could explain the less efficient results obtained by addition with the highest dose of enzyme.

\section{Viscosity, digestibility and $\mathrm{pH}$}

Viscosity. Enzyme addition reduced viscosity in both jejunum $(\mathrm{P}<0.007)$ and ileum $(\mathrm{P}<0.05)$ in most of the groups (Table 3 ). Viscosity measured in the intestinal content collected from the chickens fed diet L was not significantly different from the control group. A significant correlation was found between $\mathrm{FC}$ and log viscosity of the jejunum $(r=0.64, P<0.0002)$ and ileum content $(r=0.47, P<0.01)$, whereas no correlations were obtained between intestinal viscosity and weight gain or feed intake.

Digestibility. The apparent digestibility coefficients (\%) of protein, fat, organic matter and crude carbohydrates in ileum content collected from the chickens at day 24 of age are given in Table 4 . The results presented in Table 4 confirm the results found on performance parameters, where chickens fed diet $M$ had better WG and $\mathrm{FC}$ than any other of the experimental groups. A significant $(\mathrm{P}<0.001)$ improvement in ileal protein digestibility was found in the chickens fed diet $\mathrm{M}$, the increase being as much as $12.4 \%$ compared with the control. Enzyme addition in the other groups increased the ileal protein digestibility on average $3.5 \%$, but not significantly different from the control group.

The highest effect of addition of the enzymes was found on the ileal fat digestibility of chickens fed diet $\mathrm{M}$, the improvement compared with the control being as high as $17.0 \%(\mathrm{P}<0.0007)$. A positive effect of addition of the low dose of enzyme was seen, the improvement being $7.4 \%$ compared with the control, but not significantly different. As seen with the ileal protein digestibility, there was no positive effect of addition of the highest dose of enzyme.

The highest ileal digestibility of organic matter was seen in chickens fed dict $\mathrm{M}$, being $8.9 \%$ better compared with the control group $(\mathrm{P}<0.02)$. The same tendency was seen concerning the ileal digestibility of crude carbohydrates, the improvement being $5.7 \%$, however, not significantly different from the control group. It can not be concluded if this improvement is due to a better digestibility of starch or degraded cell wall material. There were not significant differences between 

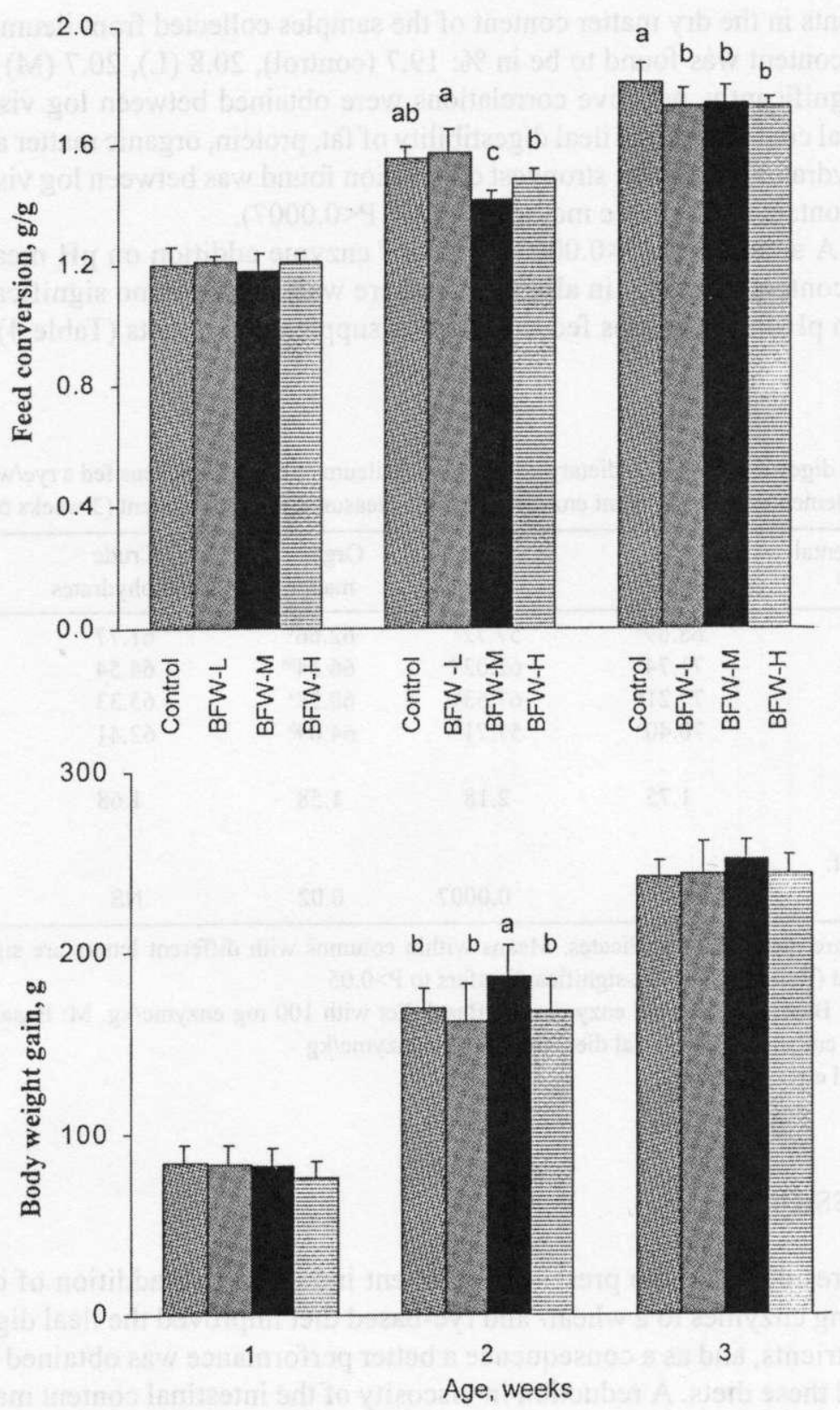

Figure 1. Effect of enzyme supplementation on weight gain ( $g$ ) and feed conversion $(\mathrm{g} / \mathrm{g})$ in week (age) 1,2 and 3, respectively. The values displayed are means and standard deviations of seven replicates. Control: Basal diet without enzymes. BFW-L: Basal diet with $100 \mathrm{mg} \mathrm{BFW/kg}$. BFW-M: Basal diet with $200 \mathrm{mg} \mathrm{BFW} / \mathrm{kg}$. BFW-H: Basal diet with $300 \mathrm{mg}$ BFW $/ \mathrm{kg}$. BFW = Bio-Feed Wheat CT 
treatments in the dry matter content of the samples collected from ileum. The dry matter content was found to be in \%: 19.7 (control), 20.8 (L), $20.7(\mathrm{M})$ and 21.1 (H). Significantly, negative correlations were obtained between $\log$ viscosity of intestinal content and the ileal digestibility of fat, protein, organic matter and crude carbohydrates, where the strongest correlation found was between log viscosity of ileum content and organic matter $(\mathrm{r}=-0.60, \mathrm{P}<0.0007)$.

$p H$. A significant $(\mathrm{P}<0.0002)$ effect of enzyme addition on $\mathrm{pH}$ measured in caecal content was seen in all groups. There was, however, no significant difference in $\mathrm{pH}$ in the groups fed the enzyme supplemented diets (Table 4).

TABLE 4 Apparent digestibility' (\%) of dietary constituents in ilcum of broiler chickens fed a rye/wheat based diet supplemented with different enzymes, and $\mathrm{pH}$ measured in caeca content (3 weeks of age)

\begin{tabular}{lccccc}
\hline \begin{tabular}{c} 
Experimental \\
\multicolumn{1}{c}{ dicts $^{2}$}
\end{tabular} & Protein & Fat & $\begin{array}{c}\text { Organic } \\
\text { matter }\end{array}$ & $\begin{array}{c}\text { Crude } \\
\text { carbohydrates }\end{array}$ & $\mathrm{pH}$ \\
\hline Control & $68.69^{\mathrm{b}}$ & $57.72^{\mathrm{b}}$ & $62.66^{\mathrm{b}}$ & 61.77 & $6.20^{\mathrm{a}}$ \\
BFW-L & $71.74^{\mathrm{b}}$ & $62.02^{\mathrm{ab}}$ & $66.14^{\mathrm{ab}}$ & 64.54 & $5.82^{\mathrm{b}}$ \\
BFW-M & $77.21^{\mathrm{a}}$ & $67.53^{\mathrm{a}}$ & $68.28^{\mathrm{a}}$ & 65.33 & $5.95^{\mathrm{b}}$ \\
BFW-H & $70.40^{\mathrm{b}}$ & $57.71^{\mathrm{b}}$ & $64.09^{\mathrm{b}}$ & 62.41 & $5.79^{\mathrm{b}}$ \\
SEM $^{3}$ & 1.75 & 2.18 & 1.58 & 1.68 & 0.18 \\
P-valuc of: & & & & & \\
Diet & 0.001 & 0.0007 & 0.02 & NS & 0.0002 \\
\hline
\end{tabular}

1 values are means of 7 replicates. Means within columns with different letters are significantly different $(\mathrm{P}<0.05)$. NS (not significant) refers to $\mathrm{P}>0.05$

2 control: Basal diet without enzymes. L: Basal diet with $100 \mathrm{mg}$ enzyme $/ \mathrm{kg}$. M: Basal diet with $200 \mathrm{mg}$ enzyme $/ \mathrm{kg}$. H: Basal diet with $300 \mathrm{mg}$ enzyme $/ \mathrm{kg}$

3 standard error of mean

\section{DISCUSSION}

The results from the present experiment indicated that addition of cell-wall degrading enzymes to a wheat- and rye-based diet improved the ileal digestibility of nutrients, and as a consequence a better performance was obtained by chickens fed these diets. A reduction in viscosity of the intestinal content may partly explain the improvement in ileal digestibility of nutrients, especially concerning the digestion of fat. Bedford and Classen (1992) demonstrated that improvements in feed conversion efficiency and weight gain in broiler chickens given rye- and wheat-based diets supplemented with xylanase was significantly corre- 
lated with a reduction in viscosity of the jejunum and ileum content. In the present experiment a negative, significant correlation was seen between $\mathrm{FC}$ and $\log$ intestinal viscosity, indicating a positive effect of viscosity reduction on FC. Addition with $200 \mathrm{mg}$ of enzyme $/ \mathrm{kg}$ (medium dose) had a very positive and statistically significant effect on almost all the measured parameters. A reduction in viscosity was also seen in chickens given diet $\mathrm{H}$, but addition with the highest dose of enzyme resulted in lower ileal digestibility of nutrients and poor weight gains of the chickens. It is believed that the highest enzyme dose in some way had a negative effect in the chickens, which probably explain the higher mortality seen in this group.

Improvements in nutrient utilization and performance of broilers fed enzyme supplemented diets based on wheat and/or rye are reported in other studies (Pettersson and Åman, 1989; Bedford and Classen, 1992; Dänicke et al., 1997; Steenfeldt et al., 1998). In the present study, ileal fat digestibility was increased by as much as $17 \%$ in chickens fed diet M. In some recent studies (Langhout et al., 1997; Dänicke et al., 1999) it has been shown that the effect of enzyme addition to wheat and/or rye based diets on performance and digestibility are considerably influenced by the fat source used. In a study by Langhout et al. (1997), addition of endo-xylanase to a diet based on wheat $(50 \%)$ and rye $(10 \%)$ improved fat digestibility significantly by $9.4 \%$ in broiler chickens when diet containing animal fat, whereas no significant improvement was obtained if the diet contained soya oil. The very high improvement in fat digestibility found in some of the treatments could be a result of using animal fat.

It has been reported by other researchers that the NSP in wheat and rye had antinutritive properties, the negative effects could be related to the content of water-soluble AX in the endosperm, which are capable of increasing digesta viscosity and reduce the digestibility and absorption of nutrients (Campbell et al., 1983; Bedford and Classen, 1992; Choct and Annison, 1992; Smulikowska and Mieczkowska, 1996; Dänicke et al., 1997). The negative effect of soluble NSP is dependent on the inclusion level of the ccreal in broiler diets, but even with lower content of wheat in diets, it is possible to get a positive response of enzyme addition (Veldmann and Vahl, 1994). In the present study the content of $\mathrm{AX}$ in wheat and rye was 6.5 and $8.1 \%$ of DM, respectively. As a result the content of AX in the experimental diet was $5.3 \%$ of DM, and soluble NSP accounted for $21 \%$ of the total NSP content in the diet. The problem with poor fat digestibility in young broiler chickens fed diets containing high level of cereals with soluble fibre can be related to different factors. Fengler and Marquardt (1988) found that as the viscosity of a solution increase, the rate of diffusion decrease, and Edwards et al. (1988) suggested that viscous polysaccharides reduce absorption due to a decrease in the convective transport of nutrients. Taking into account the large size of the fat micelle, these mechanisms could 
explain the negative effect of high intestinal viscosity on fat digestibility. In addition, bile salts are required for fat emulsification of particularly saturated fats (Kussaibati et al., 1982) and since bile salts are produced in limiting amounts in the first weeks of life in the chickens (Kroghdahl, 1985), a high intestinal viscosity could further impair fat digestibility in the young chick. In a recent study by Smits et al. (1998) it was suggested that high intestinal viscosity caused by viscous fibres decreased fat digestibility by reducing the effective concentration of bile acids in the digesta. A secondary effect of increased intestinal viscosity is an increased microbial activity, which has shown to stimulate the deconjugations of bile acids in the intestine and having a negative effect on fat digestibility (Langhout, 1999). The ileal digestibility of fat was significantly depressed by $59 \%$ by addition of isolated NSP $(66 \mathrm{~g} / \mathrm{kg}$ diet $)$, showing the dramatic effect of soluble NSP in the intestinal system of broiler chickens, however, enzyme addition eliminated the negative effect of the NSP-fraction (Choct et al., 1996). In the experiment performed by Choct et al. (1996) an increased production of VFA was observed indicating an increased microbial fermentation probably caused by the degradation of NSP to smaller components by the exogenous enzymes. In the present experiment $\mathrm{pH}$ was significantly $(\mathrm{P}<0.0002)$ decreased in chickens fed the enzyme supplemented diets compared with the control group. Concentration of VFA in intestinal content was not measured in the present experiment but the lower $\mathrm{pH}$ could indicate an increased microbial fermentation of smaller carbohydrate components not absorbed in the small intestine of the chickens.

Improvements in the ileal digestibility of protein varied in the range from 2.5 to $12.4 \%$, being statistically significant in chickens fed diet $\mathrm{M}$. The main part of the protein in cereals is located in the cell wall rich fraction as shown by Bach Knudsen at al. (1995), where comprehensive analyses of different fractions of wheat kernels revealed that the highest content of protein was found in the mill fractions enriched in aleurone tissue. However, the highest amount of AX and cellulose was found in the pericarp/testa and aleurone fractions, making digestion of protein less efficient. Addition of $200 \mathrm{mg}$ enzyme $/ \mathrm{kg}$ improved protein digestibility considerably with $12.4 \%$, indicating that disruption of cell wall material and an increased availability of protein could be partly responsible for the improved digestibility with this diet. Improvements in the ileal digestibility of total organic matter and crude carbohydrates confirmed the trends seen with digestibility of fat and protein, the effects being most pronounced with diet $M$.

It can be concluded that addition of medium dose (diet M) of enzyme caused significant improvements in nutrient digestibility and performance of chickens. It is believed that the positive effect of enzyme addition with medium dose is partly explained by a reduction in viscosity, especially concerning fat digestibility. In addition, disruption of cell wall material by the enzymes could probably 
increase the availability of cell wall bound protein. The poor effect on digestibility and performance in chickens feed diet $\mathrm{H}$ (highest dose) conflict with the reduction seen in intestinal viscosity measured in these chickens, but it is believed that the highest enzyme dose in some way had a negative effect in the chickens, which probably also explain the higher mortality seen in this group.

\section{REFERENCES}

Åman P., Hesselman K., 1984. Analysis of starch and other main constituents if cereal grains. Swed. J. Agr. Res. 14, 135-139

Association of Official Analytical Chemists, 1990. Official Methods of Analysis. 15th Edition. AOAC, Arlington, VA

Bach Knudsen K.E., 1997. Carbohydrate and lignin contents of plant material used in animal feeding. Anim. Feed Sci. Tech. 67, 319-338

Bach Knudsen K.E., Steenfeldt S., Børsting C.F., Eggum B.O., 1995. The nutritive value of decorticated mill fractions of wheat. 1. Chemical composition of raw and enzyme treated fractions and balance experiments with rats. Anim. Feed Sci. Tech. 52, 205-225

Bacic A., Stone, B.A., 1981 Chemistry and organisation of aleurone cell wall components from wheat and barley. Aust. J. Plant Physiol. 8; 475-595

Bedford M.R., Classen H.L., 1992. Reduction of intestinal viscosity through manipulation of dietary rye and pentosanase concentrations is effected through changes in the carbohydrate composition of the intestinal aqeous phase and results in improved rates and food conversion efficiency of broiler chicks. J. Nutr. 122, 137-142

Campbell G.L., Classen H.L., Goldsmith K.A., 1983. Effect of fat retention on the rachitogenic effect of rye fed to broiler chicks. Poultry Sci. 62, 2218-2223

Choct M., Annison G., 1992. Antinutritive effect of wheat pentosans in broiler chickens: Role of viscosity and gut microflora. Brit. Poultry Sci. 33, 821-934

Choct M., Huges R.J., Wang J., Bedford M., Morgan A.J., Annison G., 1996. Increased small intestinc fermentation is partly responsible for the anti-nutritive activity of non-starch polysaccharides in chickens. Brit. Poultry Sci. 37, 609-621

Dänicke S., Jeroch H., Simon O., Bedford M.R., 1999. Interactions between dietary fat type and exogenous enzyme supplementation of broiler diets based on maize, wheat, triticale or barley. J. Anim.Feed Sci. 8, 467-483

Dänicke S., Simon O., Jeroch H., Bedford M., 1997. Interactions between dietary fat type and xylanase supplementation when rye-based diets are fed to broiler chickens. 2. Performance, nutrient digestibility and the fat-solubie vitamin status of livers. Brit. Poultry Sci. 38, 546-556

Edwards C.A., Johnson I.T., Read N.W., 1988. Do viscous polysaccharides slow absorption by inhibiting diffusion or convection? Eur. J. Cin. Nutr. 42, 306-312

Fengler A.I., Marquardt R.R., 1988. Water-soluble pentosans from rye: II. Effects of rate of dialysis and on the retention of nutrients by the chick. Cereal Chem. 65, 298-302

Jacobsen E. E., 1981. Sugar and starch (LHK). New analysis method. Information from Bioteknisk Institut A.T.V. 98, 39-54

Kussaibati R., Guillaume J., Leclercq B., Lafont J.P., 1982. Effects of the intestinal microflora and added bile salts on the metabolisable energy and digestibility of saturated fats in the chicken. Arch. Geflügelk. 46, 42-46 
Kroghdahl $\AA ., 1985$. Digestion and absorption of lipids in poultry. J. Nutr. 115, 675-685

Langhout D.J., Schutte J.B., Geerse C., Kies A.K., De Jong J., Verstegen M.W.A., 1997. Effects on chick performance and nutrient digestibility of an endo-xylanase added to a wheat-and rycbased diet in relation to fat source. Brit. Poultry Sci. $38,557-563$

Langhout D.J., 1999. The role of the intestinal flora as affected by NSP in broilers. In: Proceedings of the $12^{\text {th }}$ European Symposium on Poultry Nutrition, Veldhoven (The Netherlands), pp. 203212

National Research Council, 1994. Nutrient Requirements of Poultry. $9^{\text {th }}$ revised Edition. National Academic Press, Washington DC

Mares D.J., Stone B. A., 1973. Studies on wheat endosperm. I. Chemical composition and ultrastructure of the cell walls. Aust. J. Biol. Sci, 26, 793-812

Pettersson D., Aman P., 1989. Enzyme supplementation of a poultry diet containing rye and wheat. Brit. J. Nutr. 62, 139-149

Scott M.J., Nesheim M.C., Young R.J., 1982. Nutrition of the Chicken. 3rd Edition. Cornell University, Ithaca, New York

Shürch A., Lloyd L. E., Crampton, E.W., 1950. The use of chromic oxide as an indeks for determin. ing the digestibility of a diet. J. Nutr. 50, 629-636

Statistical Analysis Systems Institute Inc., 1990. SAS/STAT Guide for Personal Computers. SAS Institute Inc., Cary, NC

Smits C.H.M., Veldman A., Verkade H.J., Beynen A.C., 1998. The inhibitory effect of carboxymethylcellulose with high viscosity on lipid absorption in broiler chickens coincides with reduced bile salt concentration and raised microbial numbers in the small intestine. Poultry Sci. 77, 1534-1539

Smulikowska S., Mieczkowska A., 1996. Effect of rye level, fat source and enzyme supplementation on fat ulilisation, diet metabolisable energy, intestinal viscosity and performance of broiler chickens. J. Anim. Feed Sci. 5, 379-393

Steenfeldt S., Hammershøj M., Müllertz A., Jensen F.J., 1998. Enzyme supplementation of wheatbased diets for broilers 2 . Effect on apparent metabolisable energy and nutrient digestibility. Anim. Feed Sci. Tech. 75, 45-64

Stoldt W., 1952. Verslag zur Vereinheitliching der Fettbestimmung in Lebensmitteln. Fette, Seifen, Anstrichm. 54, 206-207

Veldman A., Vahl H.A., 1994, Xylanase in broiler diets with differences in characteristics and content of wheat. Brit. Poultry Sci. 35, 537-550 


\section{STRESZCZENIE}

Poprawa strawności składników pokarmowych i wyników produkcyjnych kurcząt brojlerów żywionych dietą pszenną lub żytnią uzupelnioną énzymami

Celem doświadczenia było zbadanie wpływu zwiększenia poziomu preparatów enzymatycznych na lepkość treści, strawność w jelicie biodrowym i wyniki produkcyjne kurcząt brojlerów żywionych od 0 do 2 l dnia życia dietą zawierająca pszenicę i ży to w ilości odpowiednio 63 i 9,35\%. Skarmiano 4 dicty, zawierające 11,98 MJ EM/kg paszy i 19,25\% białka: kontrolna (dieta podstawowa), L, M i H (dieta podstawowa $+100,200$ lub $300 \mathrm{mg} \mathrm{Bio-Feed} \mathrm{Wheat} \mathrm{CT} / \mathrm{kg}$ ), odpowicdnio. Wykorzystanie paszy przez kurczęta otrzymujące dietę $\mathrm{M}$ było istotnie lepsze $(\mathrm{P}<0,002)$ w porównaniu $z$ grupą kontrolną i i kurczętami otrzymującymi dietę L, o 5,0 i 3,3\%, odpowiednio. Przyrosty kurcząt grupy $\mathrm{M}$ zwiększyły sį̧ o 5,3\% i róźniły się istotnic $(\mathrm{P}<0,008)$ od przyrostów kurcząt w pozostałych grupach. Dodatek enzymu obniżył lepkość treści w jelicie czczym $(\mathrm{P}<007)$ i jelicie biodrowym $(\mathrm{P}<0,05)$, $\mathrm{z}$ wyjątkiem grupy L. U kurcząt grupy $\mathrm{M}(\mathrm{P}<0,001)$ zwiększyła się strawność białka w jelicie biodrowym, o 12,4\%, w porównaniu z kontrolną, co potwicrdza uzyskanc lepsze wyniki produkcyjne w tej grupie. Dodatek enzyma w pozostałych grupach zwiększył strawność białka w jelicie biodrowym o $3,5 \%$, lecz różnica ta nie była istotna w porównaniu z grupą kontrolną.

Dodatek enzymu wpłynął znacząco na strawność tłuszczu w jelicie biodrowym kurcząt otrzymujących dicty $\mathrm{M}$, zwiększając ją o $17 \%$ ( $\mathrm{P}<0,0007$ ), a także na poprawę strawności jelitowej substancji organicznej, która wzrosła o $8,9 \%$, porównaniu z grupą kontrolną. 